\title{
A Qualitative Study of Marital Satisfaction and the Newlyweds of Depok
}

Aditya Benyamin ${ }^{\mathrm{a}}$, Alvin Theodorus Larosa ${ }^{\mathrm{b}}$, Syifa Amania Afrac ${ }^{\mathrm{c}}$, and Eko Handayani $^{\mathrm{d}}$

${ }^{a}$ Faculty of Psychology, Universitas Indonesia, Depok, Indonesia; ${ }^{b}$ Faculty of Psychology, Universitas Indonesia, Depok, Indonesia; ${ }^{c}$ Faculty of Administrative Science, Universitas Indonesia, Depok, Indonesia; ${ }^{d}$ Department of Developmental Psychology, Faculty of Psychology, Universitas Indonesia, Depok, Indonesia

*Corresponding author:

Eko Handayani

Department of Developmental Psychology

Faculty of Psychology, Universitas Indonesia

Jl. Lkr. Kampus Raya, Depok, Jawa Barat

Indonesia, 16424

Tel.: +62 217270004

Email address: $\underline{\text { anipsy@ui.ac.id }}$ 


\title{
A Qualitative Study of Marital Satisfaction and the Newlyweds of Depok
}

\begin{abstract}
Divorce is a serious problem in Depok city. This might be due to low marital satisfaction since people with lower marital satisfaction have a higher risk of divorce. Using a qualitative approach, this paper explores which dimensions of marital satisfaction contribute the most to challenges faced by newlyweds in Depok. In-depth-interviews were conducted with six individuals who had been married for a maximum of five years and did not have any children. The data obtained were analyzed using directed content analysis. Results showed that from the ten dimensions of marital satisfaction assessed, communication, personality, family and friends, and financial management were the most common causes of the problems couples faced. Communication was mentioned the most, specifically, problems with comfortably exchanging emotional information. Problems with personality referred to unfulfilled expectations of a spouse's behavior. In the dimension of family and friends the most mentioned problem was the spouse's parents. Problems budgeting and handling egos while resolving financial issues were mentioned in the dimension of financial management. The implications of these results for future interventions and government policy are discussed.
\end{abstract}

Keywords: marital satisfaction, divorce, intervention

\section{Introduction}

Divorce is becoming a serious problem in Indonesia. Nationwide, the number of divorces has reached $17.7 \%$ of married couples (Badan Peradilan Agama Mahkamah Agung RI in Mukhtar, 2016). According to the National Population and Family Planning Council or Badan Kependudukan dan Keluarga Berencana Nasional in 2016, Indonesia has the highest divorce rate of all the Asia Pacific countries (BKKBN; in Purnawan, 2016), and Depok city is particularly vulnerable to this phenomenon. Citywide, Depok has the highest divorce rate in the West Java province, which has the third highest divorce rate in Indonesia (Ahmadi, Ashrafi, Kimiaee \& Afzali, 2010; Badan Peradilan Agama Mahkamah Agung RI in Mukhtar, 2016). This phenomenon needs to be given extra attention since previous studies have shown that divorce has a negative impact on all individuals involved, and even on the society where it occurs. Amato (2012) found that individuals who are involved in divorce proceedings (husband, wives, and also children) tend to have poorer well-being. Individuals involved in divorce proceedings experience more symptoms of depression and other problems (Amato, 2012). Children of divorced parents also tend to show more externalizing problems (e.g., being in fights, rule breaking, truancy; Lansford, Malone, Castellino, Dodge, Pettit \& Bates, 2006), and lower academic achievement (Potter, 2010). Conflict, and the parents' ability to solve it, affects children's level of anxiety and self-esteem which can be carried over into adulthood. This might also be a spill-over effect of the quality of parents' relationship on their parenting behavior (US Department of Health and Human Services, 2009). From a wider perspective, divorce is an economic burden for a country. In the United States in 2006 for example, divorce was estimated to cost the nation about 33.3 billion dollars annually (Schram, 2006). 
As divorce impacts upon the individuals involved as well as society as a whole, the government must take action to buffer the impact, and prevent couples from getting divorced. Previous interventions by the Indonesian government such as the Program Keluarga Harapan (Hope Family Programme) have focused on economic aspects of married life, while the social and psychological aspects of married life have been ignored. This intervention was not built on existing scientific studies in the area of marriage dissolution. On the other hand, there are interventions that target psychological issues, and that are based on empirical research, such as the ENRICH program (Fowers \& Olson, 1989). Unfortunately none have been adapted to Indonesian culture, therefore, they may have questionable validity due to poor cultural sensitivity if applied to the Indonesian, or more specifically, the Depok population. This calls for the development of a scientifically-based intervention that is culturally sensitive, and has proven validity with the Depok population.

As a first step on the journey to creating an effective preventive intervention to this alarming divorce rate, we are in dire need of an assessment of the problem and its antecedents. The assessment of marriage uses two approaches which focus on the stability (success) and quality of the marriage (Spanier, 1979; US Department of Health and Human Services, 2009). While the stability of the marriage is often described in terms of how easily the union is dissolved, this study assessed the quality of marriage while the union remained intact. Marital quality itself comprised the personal assessment of the relationship by the married couple. Marital quality was the assessment tool used to identify a troubled marriage (Johnson, 1995). This concept was further interpreted as marital adjustment, happiness, functioning, and satisfaction.

In this study, the couple's interpretation of marital quality as marital satisfaction was used for two reasons. The first was the unreliability of others' interpretations, due to the impracticality of research on marital adjustment being conducted in relation to other variables, such as using a theoretical model to explain the dynamics of marital relations. Marital adjustment measures include both subjective evaluations and behavioral indicators, which create a general and less rigorous standard of measurement (Norton, 1983; Fincham \& Bradbury, 1987; Johnson, 1995) This was a crucial consideration, as this study aimed to contribute the foundation of a future intervention, which requires quantitative measurement and module development. Secondly, single-item global evaluations of happiness would not help to identify the skills newlyweds need to develop. These types of measurements only collect evaluative and behavioral indicators of marital adjustment in a very narrow context. Thus, an interpretation of marital satisfaction consisting of the couple's assessment of multiple traits that support marital quality would be a better practical tool to measure marital adjustment and inform module development.

Previous studies have shown that one of the main predictors of divorce is low marital satisfaction in particular (Røsand, Slinning, Røysamb \& Tambs, 2014). Spouses who are dissatisfied with their marriage have a higher risk of divorce than those who are satisfied. Newlyweds are especially prone to the risk of divorce, since data shows that marital satisfaction tends to deteriorate during the early years of marriage (Lavner \& Bradburry, 2011). As the amount and intensity of family stressors rise, a couple's marital satisfaction 
drops (Boss, 2002; Olson, et. al., 1989). In contrast to that, Indonesian newlyweds have quite high levels of marital satisfaction (Juwita, 2013; Lisantia, 2013; Maharti, 2015). This has also been correlated with other variables that might support the quality of one's marriage, such as love (Juwita, 2013) and commitment (Maharti, 2015). It is a shame that none of these studies tried to analyze marital satisfaction more specifically, in each of its dimensions, while having a proportionally imbalanced measurement for each. In these studies, some dimensions were measured through one item, and others through two items, which meant the average final score did not represent all dimensions to the same degree. Therefore this study is important, because it uses a proportional number of items per dimension to ensure the final score is properly weighted, and can make a properly informed contribution to understanding newlyweds in Depok.

Marital satisfaction can be defined as the perception of one's marital happiness (Fowers \& Olson, 1993). Fowers and Olson (1989) proposed 10 dimensions of marital satisfaction:

- Personality issues, which explains how satisfied spouses are with their understanding of each other's personality and behavior, and their compatibility;

- Communication, refers to how comfortable spouses are with sharing information, shown by their attitude and affection;

- Conflict resolution, describes how satisfied spouses are with the strategy, process, and outcome of resolving disagreements between them;

- Financial management, addresses spouses' spending patterns, financial decision making, and any other financial issues;

- Leisure activities, assesses how spouses manage their time for personal leisure, and time with their partner;

- Sexual relationships, covers sexuality issues, such as spouses' attitudes toward sexual activity, sexual behavior, loyalty, pregnancy planning, and how they express their affection for one another;

- Children and parenting, spouse attitudes toward having and raising children;

- Family and friends, assesses how spouses relate to their extended family (in-laws), their own family, and each other's friends;

- Equalitarian roles, focuses on how each spouse reacts to their division of roles within their family and marriage;

- Religious orientation, spouses' attitudes to religious acts and beliefs.

Before an intervention can be constructed, one must first identify common problems faced by newlyweds, and the-at-risk population in Depok city. While previous studies have shown (Røsand et al, 2014) that marital satisfaction is one of the main predictors of divorce, which dimension contributes the most and how has not yet been explored. The current study therefore aims to explore which components of marital satisfaction contribute the most to problems faced by newlyweds in Depok city, and how. 


\section{Methods}

Qualitative methods were used comprising in-depth-interviews. This method was chosen as interviews have been used in other preliminary studies assessing marital issues (Mattessich \& Hill, 1987).

\section{A. Participants}

Guided semi-structured interviews were conducted. An audio recorder and notes were also used to enrich the data collection and analysis process. The interview guidelines were constructed based on the dimensions of marital satisfaction proposed by Fowers and Olson (1989). There were at least ten key dimensions that were explored; including challenges faced as a couple related but not limited to: communication, personality, conflict management, financial management, religious orientation, sexual relationship, family and friends, children and parenting, equalitarian roles, and leisure activities. However, the semistructured nature of this method permitted the interviewer and interviewee to comment on any other topics that might have contributed to marital satisfaction. As a qualitative study, this research also explored whether there were any other dimensions of marital satisfaction unique to newlyweds in Depok. The complete interview guidelines can be found in Appendix A.

\section{B. Instruments}

Guided semi-structured interview was conducted using an interview guideline. Audio recorder and notes also used to ease the data collection and analysis process. The interview guidelines were constructed based on the dimension of marital satisfaction proposed by Fowers and Olson (1989). There are at least 10 key informations that will be explored: challenges faced as a couple that are related but not limited to communication, personality, conflict management, financial management, religious orientation, sexual relationship, family and friends, children and parenting, equalitarian roles, and leisure activities. Tough, the semistructure nature of this research made the interviewer and interviewee open to answer any other topics that might personally contribute to their marital satisfaction. As a qualitative study, this research would also like to explore whether there is any other dimension of marital satisfaction unique to newlyweds in Depok. The complete interview guidelines can be found on Appendix A.

\section{Data Collection}

All interviews were audio recorded using a smartphone and transcribed. Notes were also taken during the interviews to focus the process and subsequent analysis. All interviews were conducted at different times and locations, according to the participants' preference. All participants were acquired using a convenience or snowball sampling method. A call for participants' questionnaire was distributed using Google forms on various social media platforms (line, WhatsApp, Instagram). After the participants were recruited, they were briefly informed that this study was being conducted to explore the life of newlywed couples. The participants provided their informed consent in writing and the interviews were then conducted. 


\section{Data Analysis}

The data collected were analyzed using a direct content analysis technique (Hsieh, \& Shannon, 2005). Using this technique, firstly themes and categories were developed before the data collection process began (Hsieh \& Shannon, 2005). The themes and categories were developed based on the dimensions of marital satisfaction proposed by Fowers and Olson (1989). Indicators of each theme/categories were also developed. The categories and their indicators were as follows:

- Communication: comfort receiving and conveying (1) emotional information, and (2) cognitive information

- Conflict resolution: (1) openness to admitting and solving problem(s), (2) conflict resolution strategy

- Financial management: (1) expense patterns, (2) process of financial decision making

- Leisure activities: (1) types of leisure activities, (2) similarity and differences, (3) expectations of sharing leisure activities as a couple

- Sexual relationships: (1) problems with sexual life, (2) sexual behavior, (3) sexual fidelity, (4) contraception

- Children and parenting: (1) decisions about child discipline, (2) decisions about goal setting for children, (3) impact of children on marital life

- Family and friends: (1) comfort spending time with friends and family, (2) expectations of time spent with friends and family

- Equalitarian roles: (1) assigning roles

- Religious orientation: (1) attitudes toward religious acts and beliefs

- Personality issues: (1) perception of spouse's personality, (2) satisfaction with spouse's personality

Next, the interview audio data was transcribed verbatim. The verbatim data was then coded and organized according to existing themes/categories. Data from each theme/category was further organized into existing indicators. If we found that some data did not fit into any categories or indicators, new themes/categories/indicators were created. The significance of each category and indicator was determined by the number of times that specific category was mentioned in each individual case, and also in all cases combined (Vaismoradi, Turenen \& Bondas, 2013).

\section{Results}

The content analysis revealed that only four out of the ten dimensions of marital satisfaction were considered actual problems according to the six newlyweds interviewed. Those four dimensions were communication, personality issues, family and friends, and financial management. The theme of communication was found fourteen (14) times across all participants. This theme included how the spouse received emotional information, miscommunication, and giving advice, and how comfortable couples were delivering cognitive information. The theme of personality issues arose eleven (11) times, which included whether couples accepted each other's personality, their process of adaptation, and their expectations of the other's behavior. Family and friends was found also eleven (11) 
times, which consisted mainly of conflicts with the mother-in-law. Finally, financial management issues were mentioned seven (7) times. This theme included budgeting issues, debts, and inconsistent income. Other themes were only coded once or twice.

\section{A. Communication}

There were three challenges mentioned arising from newlywed's communication. The first was misunderstanding or miscommunication. Modes of communication played a role in creating this misunderstanding. One of the subjects, SZ, said that communicating through digital media (social media, text messages, instant messaging) often created misunderstanding. That being said, SZ also felt that this form of communication encouraged her to talk more freely than talking in person.

"Especially when we communicate using chat, usually it creates a misunderstanding.... I can speak more freely using chat, because I don't have the heart (merasa nggak enak) when talking in person"-

SZ

Another communication challenge was conveying emotional information. One of the subjects, BF, felt that he was no good at communicating emotionally loaded information and needed to reduce his ego. Finally, giving advice was also a challenge for two female subjects. When SZ was trying to give advice to her husband, her husband would cut her mid-sentence and give her advice instead, Similarly, SRM felt that her husband was reluctant to take any advice from her.

"Thank God (Alhamdullilah), so far we have never been in a fight, at most we upset each other because he is too stubborn to take any advice from me."-SRM

\section{B. Personality Issues}

Adapting to their spouse's personality was a challenge for some of our subjects. SZ perceived her husband as a sensitive person, so she felt the need to be gentle when talking to her husband. This as a challenge for SZ because she used to be very straightforward person.

"I used to be very straightforward person, but now I can't be like that with my husband because he is a rather sensitive and emotional person. So I have to be extra gentle around him"-SZ

SF also mentioned a similar experience. She mentioned that she likes everything perfectly arranged and clean while her husband is not used to being neat. The two of them also prefer to use leisure time differently. SF preferred to do household chores while her husband preferred to play sports. She saw this as a challenge that meant she needed to adapt to her husband's character and personality.

Another challenge was coping with unmet expectations of a spouse's behavior. BF felt that his wife was reluctant to take his side in the conflict between him and his in-laws. He was hurt by this because he thought that it was a wife's duty to takes her husband's side in a conflict, to protect her husband's pride. 
"My in-laws think that all I do inside our room is sleep. Although I have told my wife that I'm working inside our room, she didn't take my side. What I want to say is that the wife is supposed to protect her husband's pride"'-BF

In addition, BF also felt that his wife doesn't take care of him enough and spend sufficient time attending house chores. This unmet expectation could cause conflict. In EP's case, there were times when his wife asked for something from him and when he didn't fulfill her request, so, she got irritated. In addition to that, his wife was also upset when she was not invited if he chose to eat outside.

\section{Family and Friends}

The most frequently mentioned challenge in the area of family and friends was conflicts/problems with parents/in-laws. One possible source of conflict was miscommunication. In BF's case, he felt that a lot of miscommunication occurred between him and his wife, and him and his in-laws. One of the reasons why miscommunication with his in-laws occurred was his tendency to engage in non-direct communication. He prefers to tell his wife to give a message to his in-laws, and in turn his wife communicates this to her parents. Another source of conflict was in-laws' prejudice. BF in-laws think badly of him because he often spends the morning in his room. While that is true, he explained that he only does that because he has spent all night working and needs time to rest.

"There's prejudice from my wife's parents that all I do is sleep"

\section{Financial Management}

One of the financial management problems mentioned in the interviews was rooted in the fact that the couple lived under the same roof as their parents/in-laws. In SZ's case, this living arrangement made it hard for her to differentiate her and her husband's expenditure from her parents'. The same problem was also faced by HNR.

"Because we still live with my parents, I'm confused about managing expense accounts"-HNR

Another challenge was related to income instability. Since BF was an entrepreneur, his monthly income fluctuated a great deal. In a good month, he could earn a high income, but in other months, not so high. Debts were also a challenge, be it the couple's debts or their parents'/in-laws'. Parents'/in-laws' debts were also a problem because sometimes the spouse felt the need to help pay off their debts. This can prevent couples from saving money due to their additional responsibilities for paying off their own debts. In BF's case, he took a loan to pay for his wedding reception.

"One of the [financial] problem I face is debts. I have a lot of debts. First, I still help my parents with their debts. So every month I send them money to pay their debts. And then I also have an installment $\mathrm{Rp} 4.000,000$ a month. I took a loan to pay for my wedding reception.... I can barely pay my loan back so I can't save money"-BF 


\section{Discussion, Added Values, and Conclusion}

\section{A. Discussion}

This study found that communication, family and friends, personality issues, and financial management were the dimensions of marital satisfaction most frequently mentioned as the source of problems faced by participants. More specifically, conveying emotional information (communication), expectations of the spouse's behavior (personality issues), conflicts with parents (family and friends), and budgeting (financial management) were the most mentioned causes of marital problems. Previous studies support some of these findings. Wu, Yeh, Cross, Larson, Wang, and Tsai (2010) conducted a study which found that conflict with mothers-in-law negatively affected a wife's marital satisfaction, but only if her husband did not support her, take her side or use problem-solving strategies.

Table 1. Challenges Faced by Depok's Newlyweds

\begin{tabular}{|l|l|}
\hline \multicolumn{1}{|c|}{ MS Dimensions } & \multicolumn{1}{c|}{ Specific Challenges } \\
\hline Communication & $\begin{array}{l}\text { 1. Misunderstanding } \\
\text { 2. Conveying emotional } \\
\text { information } \\
\text { 3. Giving advice }\end{array}$ \\
\hline Personality Issues & $\begin{array}{l}\text { 1. Personality adaptation } \\
\text { 2. Coping with unmet } \\
\text { expectations }\end{array}$ \\
\hline Friends and family & $\begin{array}{l}\text { 1. Conflicts with parents/ } \\
\text { in-laws : (1) caused by } \\
\text { miscommunication, (2) } \\
\text { caused by parents'/in-laws' } \\
\text { perceived prejudice }\end{array}$ \\
\hline Financial management & $\begin{array}{l}\text { 1. Managing expense accounts } \\
\text { 2. Own and parents'/in-laws' } \\
\text { debts } \\
\text { 3. Income instability }\end{array}$ \\
\hline
\end{tabular}

However, the current study found it was the husband who was affected most by conflicts with in-laws. Wu et al.'s (2010) study also reported that the husband felt that his wife didn't take his side enough. Furthermore, the current study offers a possible explanation why a spouse's support in conflicts with in laws matters. The husband perceived that it was a wife's duty to take her husband's side in a conflict.

In support of the current study, Cordova, Gee, and Warren (2005) found that the ability to communicate emotions was positively associated with marital adjustment. The current study further elaborated a possible explanation why this ability is so important. A spouse's personality can give a potential explanation. One participant noted that her husband was a sensitive person therefore she needed to be extra careful when delivering emotionally laden information. Another is the spouse's function as a confidant. One participant mentioned that 
her husband was her 'go to person' if she panics or feeling anxious. The inability to share such negative feelings can be a problem.

\section{B. Added Values}

In addition to contributing to marital satisfaction literature, this study could help researchers and the government to further their understanding of marital discord, and by doing so create a better foundation for more effective training programs for Depok's newlyweds. Such a program would need to tackle the four marital dimensions that contribute the most to the challenges faced by Depok's newlywed couples. This training program would have the potential to lower future divorce rates in Depok city, by increasing Depok's newlyweds' marital satisfaction. That being said, further studies exploring each dimension in more detail are needed before such training programs can be conducted. Previous interventions like the Pre-Marriage Preparation Training Program, Family Planning Ambassadors, and the Maturity Marriage Age Program did not specifically target skills related to communication, personality issues, family and parenting, and budgeting.

This study could also serve as a foundation for a policy paper/academic manuscript/policy brief. This document could then be used to inform legislators and other stakeholders involved in public policy making, so they can develop a policy grounded on sound scientific evidence.

\section{Conclusion}

This study explored which dimensions of marital satisfaction contributed the most to the challenges faced by Depok city's newlyweds, and how they contributed to them individually. Four out of the ten dimensions of marital satisfaction were identified as the source of most of the problems faced: communication, personality issues, family and friends, and financial management. These results could help both researchers and the government to build a more effective intervention designed specifically to tackle these four dimensions of marital satisfaction.

\section{References}

Boss, P. (2002). Family stress management. Thousand Oaks, CA: Sage.

Fincham, F. D., \& Bradbury, T. N. (1987). The assessment of marital quality: A reevaluation. Journal of Marriage and the Family, 49, 797-809.

Fowers, B. J., \& Olson, D. H. (1989). ENRICH marital inventory: A discriminant validity and cross-validation assessment. Journal of Marital and Family Therapy, 15(1), 65-79.

Hsieh, H.F., \& Shannon, S.E. (2005). Three approaches to qualitative content analysis. Qualitative Health Research, 15(9), 1277-1288. doi: 10.1177/1049732305276687

James V. C., Christina B. G., \& Lisa Z. (2005). Emotional skillfulness in marriage: Intimacy as a mediator of the relationship between emotional skillfulness and marital satisfaction. Journal of Social and Clinical Psychology, 24(2), 218-235. https://doi.org/10.1521/jscp.24.2.218.62270

Johnson, D. R. (1995). Assessing marital quality in longitudinal and life course studies. Family Assessment, 10, 155-202. http://digitalcommons.unl.edu/cgi/viewcontent.cgi?article=1009\&context=burosfamily

Juwita, R. (2013). The relationship between love and marital satisfaction among individuals in the early stage of marriage. (Unpublished undergraduate's mini thesis). Depok: Universitas Indonesia. 
Lavner, J. A., \& Bradburry, T. N. (2011). Patterns of change in marital satisfaction over the newlywed years. Journal of Marriage and Family, 72(5), 1171-1187.

Lisantia. (2013). The relationship between love and marital satisfaction in first-time parent. (Unpublished undergraduate's mini thesis). Depok: Universitas Indonesia.

Maharti, H. M. (2015). Interrelation between marital satisfaction, religious commitment, and marital commitment in Indonesia. (Unpublished undergraduate's mini thesis). Depok: Universitas Indonesia.

Mattessich, P., \& Hill, R. (1987). Life cycle and family development. In M. B. Sussman \& S. K Steinmetz (Eds.), Handbook of marriage and the family (pp. 437-469). New York: Plenum Press.

Norton, R. (1983). Measuring marital quality: A critical look at the dependent variable. Journal of Marriage and the Family, 45, 141-151.

Olson, D. H., \& DeFrain, J. (2006). Marriage and families: Intimacy, diversity, and strengths (5th ed.). New York: McGraw Hill.

Olson, D. H., McCubbin, H. I., Barnes, H., Larson, A., Muxen, M., \& Wilson, M. (1989). Families: What makes them work (2nd ed.). Los Angeles, CA: Sage.

Røsand, G. M. B., Slinning, K., Røysamb, E., \& Tambs, K. (2014). Relationship dissatisfaction and other risk factors for future relationship dissolution: a population-based study of 18,523 couples. Social Psychiatry and Psychiatric Epidemiology, 49(1), 109-119. doi: 10.1007/s00127-013-0681-3

Spanier, G. B. (1979). The measurement of marital quality. Journal of Sex and Marital Therapy, 5(3), 288-300. doi: 10.1080/00926237908403734

US Department of Health and Human Services. (2009). Marital quality and outcomes for children and adolescents: A review of the family process literature. Marriage and Family Review, 45(2/3).

Vaismoradi, M., Turunen, H., \& Bondas, T. (2013). Content analysis and thematic analysis: Implications for conducting a qualitative descriptive study. Nursing \& Health Sciences, 15(3), 398-405.

Wu, T., Yeh, K., Cross, S. E., Larson, L. M., Wang, Y., \& Tsai, Y. (2010). Conflict with mothers-in-law and Taiwanese women's marital satisfaction: the moderating role of husband support. The Counseling Psychologist, 38(4), 497-522. doi: 10.1177/0011000009353071 


\section{APPENDIX A-INTERVIEW GUIDELINE}

1. Introduction of interviewer and the purpose of the study

2. Request interviewee to read and sign the Inform Consent

3. Could you please introduce yourself - age, address, age of marriage, daily profession/activities (wife and husband)?

4. Could you please let us know how you both met and eventually decided to marry?

5. What do you think are the challenges you face as a newlywed?

(probe accordingly, to ensure whether all the dimension according to the theory is realized by the couple)

6. How about the challenges in term of your communication with your partner: comfortability in receiving and conveying (1) emotional information, and (2) cognitive information?

7. How about the challenges in term of your conflict resolution with your partner: (1) openness to admit and solve problem(s), (2) conflict resolution strategy?

8. How about the challenges in term of your financial management: (1) expense pattern, (2) process of financial decision making?

9. How about the challenges in term of your leisure activities spent with your partner: (1) type of leisure activities, (2) similarity and differences, (3) expectation to do leisure activities as a couple?

10. How about the challenges in term of your sexual relationships: (1) problems regarding sexual life, (2) sexual behavior, (3) sexual fidelity, (4) contraception?

11. How about the challenges in term of your how you handle your children and parenting issues: (1) decision regarding child discipline, (2) decision regarding setting goals for children, (3) impact of children on marital lifes?

12. How about the challenges in term of your relation with family and friends: (1) comfortability in spending times with friends and family, (2) expectation regarding time spent with friends and family?

13. How about the challenges in term of your effort in creating equalitarian roles: (1) assigning role?

14. How about the challenges in term of your religious orientation together with your partner: (1) attitude toward the meaning of religious acts and beliefs?

15. How about the challenges in term of your personality issues, whether it is your own or your partner: (1) perception of spouse's personality, (2) satisfaction regarding spouse's personality?

16. Out of all of those things you mentioned before, which ones would you rate as the biggest challenge in your marriage life so far? 